Biol. Stud. 2020: 14(4); 15-22 • DOI: https://doi.org/10.30970/sbi.1404.635

www.http://publications.Inu.edu.ua/journals/index.php/biology

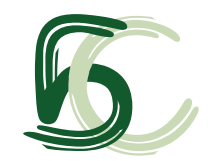

UDC: $577.35+576.38$

\title{
PROOXIDANT AND ANTIOXIDANT PROCESSES IN LYMPHOMA CELLS UNDER THE ACTION OF PYRAZOLOPYRIMIDINE DERIVATIVE
}

\author{
Ya. R. Shalai@1*, M. V. Popovych ${ }^{\circledR 1}$, S. M. Mandzynets ${ }^{\circledR 1}$, \\ V. P. Hreniukh ${ }^{1}$, N. S. Finiuk ${ }^{2}$, A. M. Babsky ${ }^{1}$ \\ ${ }^{1}$ Ivan Franko National University of Lviv, 4, Hrushevskyi St., Lviv 79005, Ukraine \\ ${ }^{2}$ Institute of Cell Biology, NAS of Ukraine, 16, Drahomanov St., 79005 Lviv, Ukraine \\ *Corresponding author e-mail: Yaryna.Shalay@Inu.edu.ua
}

Shalai Ya.R., Popovych M.V., Mandzynets S.M., Hreniukh V.P., Finiuk N.S., Babsky A.M. Prooxidant and antioxidant processes in lymphoma cells under the action of pyrazolopyrimidine derivative. Studia Biologica, 2020: 14(4); 15-22 • DOI: https://doi.org/10.30970/sbi.1404.635

Background. The influence in vitro of thiazole derivative 8-methyl-2-Me-7-[trifluoromethyl-phenylmethyl]-pyrazolo-[4,3-e]-[1,3]-thiazolo-[3,2-a]-pyrimidin-4(2H)-one (PP2) on the level of lipid peroxidation products, superoxide anion radical and antioxidant system activity in lymphoma cells was studied. A pronounced cytotoxic action of the thiazole derivative on the tumor cells in vitro was reported earlier, however, no cytotoxicity of this substance was detected toward non-cancerous cells. In addition, it was shown that the scavengers of active forms of Oxygen significantly reduced the cytotoxic effect of the studied compound. The purpose of this work was to investigate the effect of 8-methyl-2-Me-7-[trifluoromethyl-phenylmethyl]-pyrazolo-[4,3-e]-[1,3]-thiazolo-[3,2-a]pyrimidin- $4(2 \mathrm{H})$-one on the content of lipid peroxidation products, superoxide radical and the activity of enzymes of antioxidant defense in the lymphoma cells.

Materials and Methods. Experiments were conducted on white wild-type male mice with grafted NK/Ly lymphoma. Ascites tumor cells were passaged by the intreperitoneal inoculation to mice. Abdominal drainage with ascites was performed with a sterile syringe under ether anesthesia. PP2 was dissolved in dimethylsulfoxide. The product content and enzymatic activity were determined spectrophotometrically. Statistical analysis of obtained results was carried out using MS Excel-2013 program.

Results. The influence of the pyrazolopyrimidine derivative on the content of lipid peroxidation products and superoxide radical in lymphoma cells was investigated. It was found that the studied compound did not change the amount of the primary lipid peroxidation products, but reduced the amount of secondary products. A decrease in the MDA content under the action of the studied derivative indicates probable interaction of the substance with the reactive Oxygen species. Pyrazolopyrimidine derivative did not change the level of the superoxide radical.

(C) 2020 Ya. R. Shalai et al.; Published by the Ivan Franko National University of Lviv on behalf of Біологічні Студії / Studia Biologica. This is an Open Access article distributed under the terms of the Creative Commons Attribution License (http://www.budapestopenaccessinitiative.org and Creative Commons Attribution 4.0 License), which permits unrestricted reuse, distribution, and reproduction in any medium, provided the original work is properly cited.

ISSN 1996-4536 (print) • ISSN 2311-0783 (on-line) • Біологічні Студії / Studia Biologica • 2020 • Том 14/№ 4 • C. 15-22 
The effect of the thiazole derivative on the activity of key enzymes of the antioxidant system in lymphoma cells was investigated. The studied compound the concentration of $10 \mu \mathrm{M}$ activated superoxide dismutase. Pyrazolopyrimidine derivative decreased the activity of catalase and glutathione peroxidase. Such changes in the activity of enzymes can cause the growth of hydrogen peroxide in the cell, which is toxic in large quantities.

Conclusions. The obtained results may indicate that the studied pyrazolopyrimidine derivative can realize its cytotoxic effect on lymphoma cells though the action on the products of lipid peroxidation and antioxidant system activity. These data can be used to understand the mechanism of action of the studied compounds and for further improvement of their antitumor effect.

Keywords: lymphoma, pyrazolopyrimidine derivative, lipid peroxidation, antioxidant system, antitumor drugs

\section{INTRODUCTION}

Neoplasmic transformation of tissues is accompanied by a change in redox balance, which depends on an increase in the level of reactive oxygen species (ROS). This effect leads to the activation of lipid peroxidation (LPO) [1]. LPO takes place in almost all cellular structures, including mitochondria, microsomes, lysosomes, endoplasmic reticulum, etc. However, increasing the intensity of this process can cause significant damage to normal and tumor cells.

Many antitumor compounds realize their cytotoxic effect via increasing the level of ROS in the cell [9]. However, the role of the products of free radical oxidation and enzymes of the antioxidant system in the mechanism of these compounds' action is not clearly understood.

Recently, pyrazolopyrimidine derivatives were established as a promising substances for the development effective antitumor drugs [3]. It was found that these substances have high cytotoxicity against various tumor cells [3, 4]. It was shown that heterocycles (thiazole) present in the structure can determine the cytotoxic properties of substances and their specificity [7]. We also found that the cytotoxicity of these derivatives depended on the presence of ROS in the cell [4].

Thus, the study of lipid oxidation processes and antioxidant activity in cancer cells under the action of new antitumor compounds is essential for understanding the mechanism of action and increasing their effectiveness.

\section{MATERIALS AND METHODS}

Experiments were conducted with white wild-type male mice (20-30 g) with grafted NK/Ly lymphoma. Animals were kept in vivarium with standard conditions (constant temperature and mixed ration). All manipulations with animals were conducted in accordance with "General ethical principles of experimentation on animals" approved by the First National Congress on Bioethics (Kyiv, Ukraine, 2001) and "European Convention for the Protection of Vertebrate Animals used for Experimental and Other Scientific Purposes" (Strasbourg, France, 1985).

The bioethical examination of the experiments carried out at the Biological Faculty of the Ivan Franko National University of Lviv was executed in the form of a protocol No. 15102020 of October 15, 2020.

ISSN 1996-4536 (print) • ISSN 2311-0783 (on-line) • Біологічні Студії / Studia Biologica • 2020 • Том 14/№ 4 • С. 15-22 
Tumor cells ascites were passaged by the intreperitoneal inoculation of $10-15 \times 10^{6}$ cells to mice. The abdominal drainage of ascites was performed with a sterile syringe under ether anesthesia for 8-14 days after inoculation. The number of cells was counted in the Goryaev chamber in a suspension diluted 50 times.

Thiazole derivatives were synthesized at the Department of Organic Chemistry of Ivan Franko National University of Lviv (the head of a department - Dr., Professor M. Obushak). The steps of synthesis are described in detail in our previous publication [3]. From the range of the synthetized compounds 8-methyl-2-Me-7-[trifluoromethylphenylmethyl]-pyrazolo-[4,3-e]-[1,3]-thiazolo-[3,2-a]-pyrimidin-4(2H)-one (PP2) was chosen for this study.

PP2 was dissolved in dimethylsulfoxide (DMSO, the final concentration did not exceed $5 \%$ ), added to lymphoma homogenate at final concentrations of 1,10 and $50 \mu \mathrm{M}$, and incubated for 10 min.

The content of lipid hydroperoxides in the homogenate of lymphoma was determined by the method based on precipitation of the protein with trichloroacetic acid, followed by the addition of ammonium thiocyanate [11]. The content of lipid hydroperoxides is presented in a conventional unit/min $\times \mathrm{mg}$ of protein. The content of TBA-positive products was evaluated according to the amount of formed malonic dialdehyde (MDA) [13]. The content of MDA is presented in $\mu$ moles $/ \mathrm{mg}$ of protein.

The formation of superoxide anion radicals in lymphoma cells was measured using the nitrosin tetrazolium test [2]. The amount of superoxide radical is presented in nmoles/g×s.

Superoxide dismutase (SOD) activity was measured by the method of V. Kostyuk et al. [6]. The activity of SOD is presented as activity units/mg of protein. Catalase activity was measured spectrophotometrically by the method of M. Korolyuk et al. [5] at an absorption wave length of $410 \mathrm{~nm}$. The enzyme activity is presented in nmoles of $\mathrm{H}_{2} \mathrm{O}_{2}$ /min $\times$ mg of protein. Glutathionperoxidase (GPO) activity was measured by the method of Moin [10]. Enzyme activity was expressed in $\mu \mathrm{M}$ of $\mathrm{G}-\mathrm{SH} / \mathrm{min} \times \mathrm{mg}$ of protein. The concentration of protein in each sample was determined by the method of O. Lowry et al. [8].

Statistical analysis of the obtained results was carried out using the MS Excel-2013 program. To assess the reliability of the difference between the statistical characteristics of the two alternative sets of data, the Student's coefficient was calculated. One-way analysis of variance was used to estimate the significance of PP2 effect in three concentrations. The difference was considered to be significant from $\mathrm{P}<0.05$.

\section{RESULTS AND DISCUSSION}

Figure 1 shows changes in the content of primary LPO products (hydroperoxides) in lymphoma under the action of PP2. Control levels of hydroperoxides were $\sim 0.06-$ 0.07 c. u./mg of protein and were taken as $100 \%$. It was found that the level of primary products of LPO in lymphoma cells under the action of PP2 did not change significantly (Fig. 1).

Figure 2 shows the changes in the amount of secondary products of LPO (TBApositive product, MDA) in lymphoma under the action of PP2. The control level of MDA was found to be $0.079-0.092 \mu \mathrm{mol} / \mathrm{mg}$ of protein and was taken as $100 \%$. The content of LPO secondary products under the action of PP2 at concentrations of 10 and $50 \mu \mathrm{M}$ decreased by $45 \%$ and $59 \%$ ( $P<0.01$ and $P<0.001)$, respectively (Fig. 2). One-factor analysis established a dose-dependent manner of these effects.

ISSN 1996-4536 (print) • ISSN 2311-0783 (on-line) • Біологічні Студії / Studia Biologica • 2020 • Том 14/№ 4 • С. 15-22 

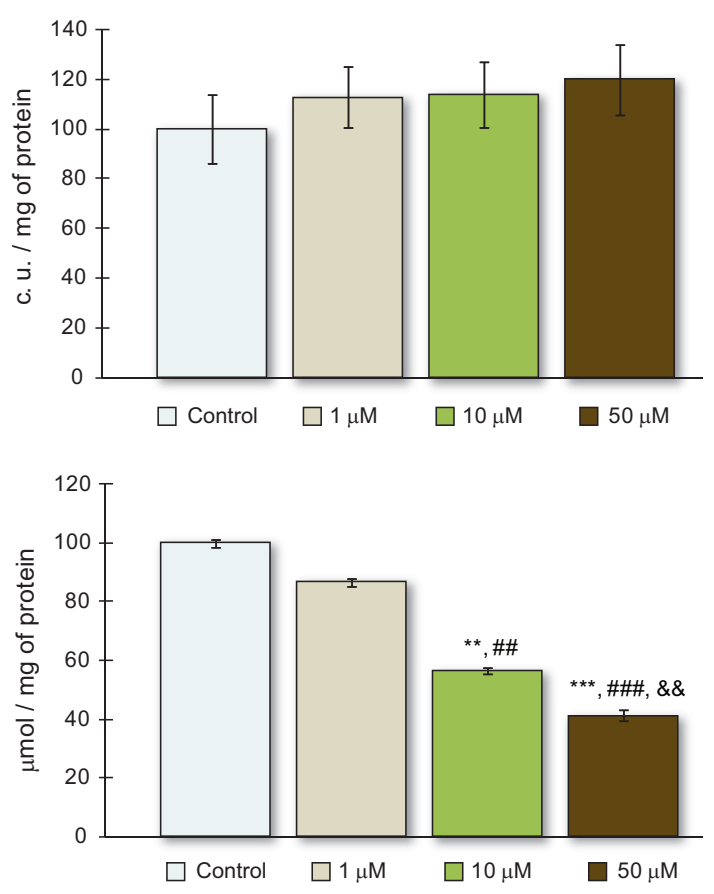

Fig. 1. The amount of lipid hydroperoxides in lymphoma under the action of PP2. $\mathrm{M} \pm \mathrm{m} ; \mathrm{n}=5$

Рис. 1. Вміст гідропероксидів ліпідів у лімфомі за дії PP2. $M \pm m, n=5$

Fig. 2. The amount of malonic dialdehyde in lymphoma under the action of PP2. $\mathrm{M} \pm \mathrm{m} ; \mathrm{n}=5$. Significance: ${ }^{* *}-\mathrm{P}<0.01$, *** $-\mathrm{P}<0.001$ (vs Control); ${ }^{\#}-\mathrm{P}<0.01$ (vs $1 \mu \mathrm{M}),{ }^{\# \#}-\mathrm{P}<0.001$ (vs $\left.1 \mu \mathrm{M}\right)$, \&\& $\mathrm{P}<0.01$ (vs $10 \mu \mathrm{M}$ )

Рис. 2. Вміст малонового діальдегіду в лім-

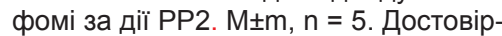
ність: ** $-\mathrm{P}<0,01$, *** $-\mathrm{P}<0,001$ (vs Control); \# $-\mathrm{P}<0,01$ (vs $1 \mu \mathrm{M}$ ), \#\# $-\mathrm{P}<0,001$ (vs $1 \mu \mathrm{M}), \& \&-\mathrm{P}<0.01$ (vs $10 \mu \mathrm{M}$ )

Figure 3 presents the content of superoxide radicals in lymphoma under the action of PP2. The control level of superoxide radicals was found to be $0.47-0.91 \mathrm{nmol} / \mathrm{g} \times \mathrm{s}$ and was taken as $100 \%$. Under the action of PP2 at all three concentrations, a tendency to reduce the amount of superoxide radical was observed, but this trend was not confirmed statistically $(P=0.18-0.61)$ (Fig. 3).

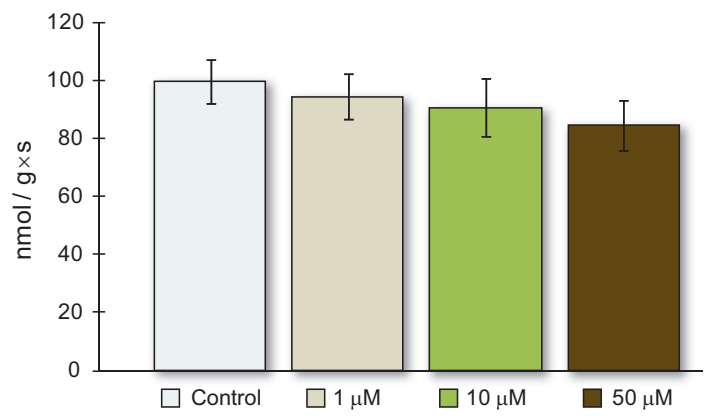

Fig. 3. The content of superoxide radical in lymphoma under the action of PP2. M \pm ; $\mathrm{n}=5$

Рис. 3. Вміст супероксидного радикалу в лімфомі за дії PP2. $\mathrm{M} \pm \mathrm{m}, \mathrm{n}=5$

Figure 4 presents the results of measuring the activity of SOD in lymphoma under the action of PP2. The control level of SOD activity in the lymphoma was $0.33-0.39$ a. u./mg of protein and it was taken as $100 \%$. Under the action of PP2 at a concentration of $10 \mu \mathrm{m}$, the activity of the enzyme increased by $37 \%(P<0.05)$ (Fig. 4).

Figure 5 shows the changes in the activity of catalase in the homogenate of lymphoma under the action of PP2. The control level of catalase was found to be $0.23-$ $0.35 \mathrm{nmol} \mathrm{H}_{2} \mathrm{O}_{2} / \mathrm{min} \times \mathrm{mg}$ of protein and was taken as $100 \%$. It was established that under the action of PP2 at concentrations of 10 and $50 \mu \mathrm{m}$ the enzyme activity decreased by $14 \%$ and $15 \%(P<0.05)$, respectively (Fig. 5). 
Fig. 4. Superoxide dismutase activity in lymphoma under the action of PP2. M \pm ; $n=5$. Significance: * $-P<0.05$

Рис. 4. Активність супероксиддисмутази за дії PP2. M $\pm m ; n=5$. Достовірність: * $P<0,05$

Fig. 5. Catalase activity in lymphoma under the action of PP2. $M \pm m . n=5$. Significance: * $-\mathrm{P}<0.05$

Рис. 5. Активність каталази в лімфомі за дії PP2. $\mathrm{M} \pm \mathrm{m}, \mathrm{n}=5$. Достовірність: * $P<0,05$
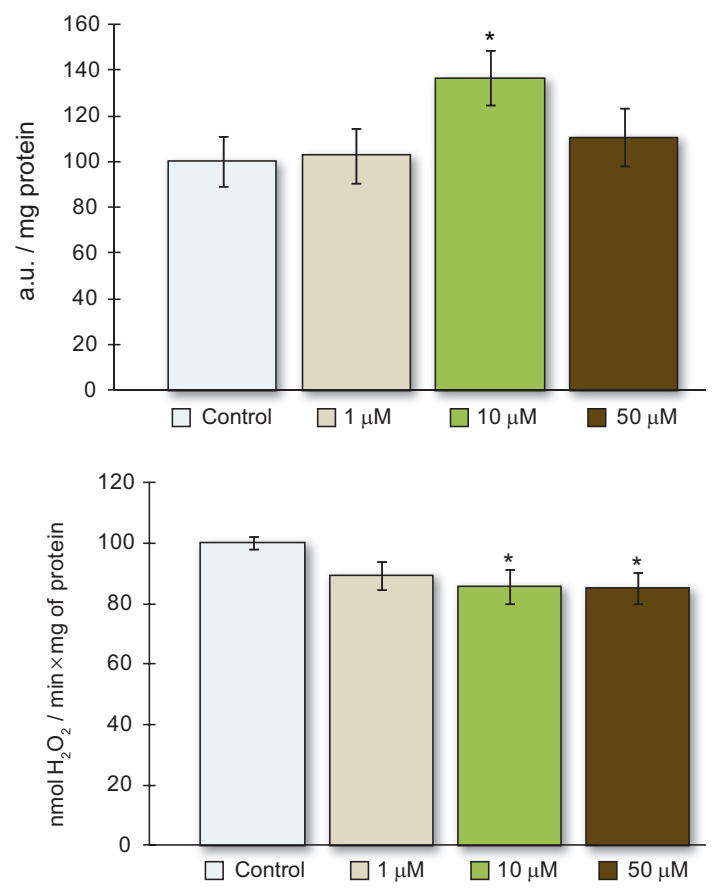

Changes in the activity of glutathione peroxidase under the action of PP2 are presented in Figure 6. The control level of the enzyme was $4.33-4.53 \mathrm{nmol}$ GSH$/ \mathrm{min} \times \mathrm{mg}$ protein and was taken as $100 \%$. The activity of glutathione peroxidase decreased under the action of PP2 at concentrations of 10 and $50 \mu \mathrm{m}$ by $41 \%(P<0.001)$ and $31 \%$ $(P<0.01)$, respectively (Fig. 6). One-factor analysis established a dose-dependent manner of these effects.

Fig. 6. Glutathione peroxidase activity in lymphoma under the action of PP2. $\mathrm{M} \pm \mathrm{m}$; $\mathrm{n}=5$. Significance: ** $-\mathrm{P}<0.01$, $^{* * *}-$ $\mathrm{P}<0.001$ (vs Control); \# $-\mathrm{P}<0.05$ (vs $1 \mu \mathrm{M}),{ }^{\#}-\mathrm{P}<0.01$ (vs $\left.1 \mu \mathrm{M}\right)$

Рис. 6. Активність глутатіонпероксидази в лім-

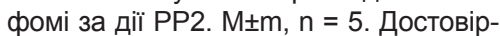
ність: ** $-\mathrm{P}<0,01,{ }^{* * *}-\mathrm{P}<0,001$ (vs Control); \# - P <0,05 (vs $1 \mu \mathrm{M})$, "\# $\mathrm{P}<0,01$ (vs $1 \mu \mathrm{M})$

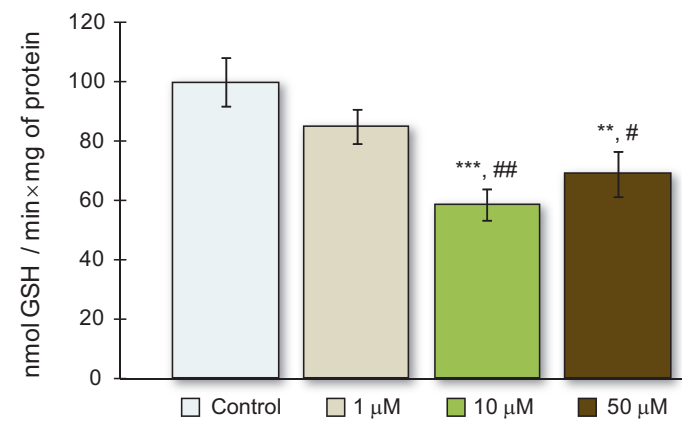

Chemotherapeutic agents that increase the oxidative stress are toxic to cancer cells because they are involved in the biological processes such as cell cycle disruption, DNA damage, and induction of apoptosis. Free radicals formed by the antitumor drugs can cause oxidative stress in tumor cells, as well as damage DNA, and induce cell death $[14,15]$.

Under the action of PP2, the content of TBA-positive products was significantly reduced by $45 \%$ and $59 \%$. Such changes can be explained by the probable interaction of PP2 with ROS, as it is known that some antitumor substances are able not only to 
generate ROS, but also to interact with them. In particular, it is known that pyrimidines can directly interact with the hydroxyl radical [12]. Therefore, PP2, as a derivative of pyrazolo-pyrimidine, can realize its cytotoxic effect through interaction with ROS.

SOD, catalase and glutathione peroxidase are key antioxidant protection enzymes. The main function of SOD is to dismantle $\mathrm{O}^{2 \cdot-}$ to hydrogen peroxide, which is reduced by catalase to water and molecular oxygen, or by glutathione peroxidase to water. Glutathione peroxidase, by catalyzing the reduction of $\mathrm{H}_{2} \mathrm{O}_{2}$, not only inactivates this metabolite, but also averts the accumulation of hydroxyl anion, preventing the formation of organic hydroperoxides. Recovery of organic hydroperoxides, especially membrane lipids by the glutathione peroxidase, reduces peroxidation and the appearance of secondary toxic metabolites [12].

Thus, the studied thiazole derivative increases the activity of SOD in lymphoma, while reducing the activity of catalase and glutathione peroxidase, which can cause the accumulation of $\mathrm{H}_{2} \mathrm{O}_{2}$ in tumor cells, which is toxic for them. These changes may cause DNA breaks, apoptosis in tumor cells and reduces the intensity of glycolysis. In view of this, SOD, catalase and glutathione peroxidase, as key antioxidant protection enzymes, may be targets for antitumor drugs, as changes in enzymatic activity will affect the level of primary and secondary products of LPO, which can be toxic to cancer cells. Thus, it can be assumed that such changes in the activity of enzymes of the antioxidant system under the action of PP2 may be part of the mechanism of increasing the sensitivity of cancer cells to antitumor factors.

\section{CONCLUSIONS}

The investigated thiazole derivative does not affect the amount of primary products of lipid peroxidation and superoxide radical in lymphoma cells. However, the action of PP2 reduces the amount of secondary products of peroxidation and changes the activity of enzymes of the antioxidant system in lymphoma cells. We hypothesize that the pyrazolopyrimidine derivative exerts its cytotoxic effect on lymphoma cells through interaction with antioxidant enzymes.

\section{COMPLIANCE WITH ETHICAL STANDARDS}

Conflict of Interest: The authors declare that the research was conducted in the absence of any commercial or financial relationships that could be construed as a potential conflict of interest.

Human Rights: This article does not contain any studies with human subjects performed by the any of the authors.

Animal studies: All institutional, national and institutional guidelines for the care and use of laboratory animals were followed.

1. Bilenko O., Rudenko M., Leus I. et al. Investigation of glutathione system under inhibition of tumor growth. Visnyk of the Lviv University. Series Blology, 2013; 62: 68-74. (In Ukrainian) Google Scholar

2. Denisenko S. V., Kostenko V. A. Changes in the production of reactive oxygen species in the testes of white rats under conditions of chronic intoxication with sodium nitrate. Modern Problems Toxicology, 2002; 4: 44-46. (In Russian) Google Scholar

3. Finiuk N.S., Hreniuh V.P., Ostapiuk Yu.V. et al. Antineoplastic activity of novel thiazole derivatives. Biopolym Cell, 2017; 33(2): 135-146.

Crossref $\bullet$ Google Scholar

ISSN 1996-4536 (print) • ISSN 2311-0783 (on-line) • Біологічні Студії / Studia Biologica • 2020 • Том 14/№ 4 • С. 15-22 
4. Finiuk N.S., Ostapiuk Yu.V., Hreniuh V.P. Shalai Ya.R., Matiychuk V.S., Obushak M.D., Stoika R.S., Babsky A.M. Evaluation of antiproliferative activity of pyrazolothiazolopyrimidine derivatives. Ukr Biochem J, 2018; 90(2): 16-23.

Crossref $\bullet$ Google Scholar

5. Korolyuk M.A., Ivanova L.I., Mayorova I.H., Tokaryev V.Ye. Method for determination of catalase activity. Lab Delo, 1988; 1: 16-19. (In Russian)

Google Scholar

6. Kostyuk V.A., Potapovich A.I., Kovaleva Zn.V. A simple, sensitive assay for determination of superoxide dismutase activity based on reaction of quercetin oxidation. Voprosy meditsinskoi khimii, 1990; 2: 88-91. (In Russian) Google Scholar

7. Kurumurthy C., Veeraswamy B., Sambasiva Rao P. et al. Synthesis of novel 1,2,3-triazole tagged pyrazolo[3,4-b]pyridine derivatives and their cytotoxic activity. Bioorg Med Chem Lett, 2014; 24(3): 746-749.

Crossref $\bullet$ PubMed $\bullet$ Google Scholar

8. Lowry O.H., Rosebrough N.J., Farr A.L., Randall R.J. Protein measurement with the folin phenol reagent. J Biol Chem, 1951; 193: 265-275.

Google Scholar

9. Menshchikova E.B., Lankin V.Z., Bondar N.K., Krugovykh N.F., Trufakin V.A. Oxidative stress. Prooxidants and antioxidants. Moscow: Slovo, 2006; 556 p. (In Russian) Google Scholar

10. Moin V.M. A simple and specific method for determining the activity of glutathione peroxidase in erythrocytes. Lab Delo, 1986; 12: 724-726. (In Russian)

PubMed • Google Scholar

11. Myronchyk V.V. Method for determination of lipid hydroperoxides in biological tissues. C. A. No 1084681 USSR, MKI; 1984. 8. (In Russian) Google Scholar

12. Nagender P., Malla Reddy G., Naresh Kumar R., Poornachandra Y., Ganesh Kumar C., Narsaiah B. Synthesis, cytotoxicity, antimicrobial and anti-biofilm activities of novel pyrazolo[3,4-b] pyridine and pyrimidine functionalized 1,2,3-triazole derivatives. Bioorg Med Chem Lett, 2014; 24(13): 2905-2908.

Crossref • PubMed $\bullet$ Google Scholar

13. Timirbulatov R.R., Seleznev E.I. The method of increasing the intensity of free radical oxidation of lipid-containing blood components and its diagnostic value. Lab Delo, 1981; 4: 209211. (In Russian)

PubMed • Google Scholar

14. Thorn C.F., Oshiro C., Marsh S., Hernandez-Boussard T., McLeod H., Klein T.E., Altman R.B. Doxorubicin pathways: pharmacodynamics and adverse effects. Pharmacogenet Genomics, 2011; 21(7): 440-446.

Crossref $\bullet$ PubMed $\bullet$ Google Scholar

15. Zandalinas S.I., Mittler R. ROS-induced ROS release in plant and animal cells. Free Radic Biol Med, 2018; 122: 21-27.

Crossref $\bullet$ PubMed $\bullet$ Google Scholar

\title{
ПРООКСИДАНТНІ Й АНТИОКСИДАНТНІ ПРОЦЕСИ У КЛІТИНАХ ЛІМФОМИ ЗА ДІЇ ПОХІДНОГО ПІРАЗОЛОПІРИМІДИНУ
}

\author{
Я. Р. Шалайін, М. В. Попович¹, С. М. Мандзинець, \\ В. П. Гренюх ${ }^{1}$, Н. С. Фінюк², А. М. Бабський \\ 1 Львівський національний університет імені Івана Франка \\ вул. Грушевського, 4, Львів 79005, Україна \\ 2 Інститут біології клітини НАН України, вул. Драгоманова, 14/16, Львів 79005, Україна; \\ *Кореспондуючий автор e-mail: Yaryna.Shalay@Inu.edu.ua
}

ISSN 1996-4536 (print) • ISSN 2311-0783 (on-line) • Біологічні Студії / Studia Biologica • 2020 • Том 14/№ 4 • С. 15-22 
Обґрунтування. Досліджено вплив in vitro похідного тіазолу 8-метил-2-Ме-7[трифрторметил-френілметил]-піразоло-[4,3-е]-[1,3]-тіазоло-[3,2-а]-піримідину-4(2H)-ону (PP2) на вміст продуктів пероксидного окиснення ліпідів, супероксидного аніон радикала й активності ферментів антиоксидантної системи у клітинах лімфоми. Раніше встановлено виражену цитотоксичну дію похідного тіазолу на клітини пухлинних ліній in vitro. Досліджувана речовина не була цитотоксичною щодо неракових клітин. Крім того, встановлено, що перехоплювачі активних форм Оксигену значно зменшують цитотоксичну дію досліджуваної сполуки. Мета роботи - дослідити дію 8-метил-2-Ме-7-[трифторметил-френілметил]-піразоло-[4,3-е]-[1,3]-тіазоло-[3,2-а]піримідин-4(2H)-ону на вміст продуктів пероксидного окиснення ліпідів, супероксидного радикала й активності фрерментів антиоксидантного захисту в клітинах лімфоми.

Матеріали та методи. Досліди виконували на нелінійних мишах-самцях з прищепленою лімфомою. Клітини пухлини асциту прищеплювали мишам внутрішньочеревною інокуляцією. Дренаж черевної порожнини проводили стерильним шприцом під ефірним наркозом. РP2 розчиняли в диметилсульфоксиді. Вміст продуктів пероксидного окиснення й активність фрерментів визначали спектрофотометрично. Статистичний аналіз отриманих результатів проводили за допомогою програми MS Excel-2013.

Результати. Досліджено вплив похідного піразолопіримідину на вміст продуктів пероксидного окиснення ліпідів і супероксидного радикала у клітинах лімфоми. Встановлено, що досліджувана сполука не змінювала рівень вмісту первинних продуктів пероксидного окиснення ліпідів, однак знижувала вміст вторинних продуктів (малоновий діальдегід). Зменшення вмісту малонового діальдегіду за дії досліджуваного похідного вказує на ймовірну взаємодію речовини з вільними радикалами та/або продуктами вільнорадикального окиснення. Похідне піразолопіримідину не змінювало рівень супероксидного радикала.

Дослідження впливу похідного піразолопіримідину на активність ключових ферментів антиоксидантної системи у клітинах лімфоми встановило, що він у концентрації $10 \mu \mathrm{M}$ активує супероксиддисмутазу. Натомість активність каталази та глутатіонпероксидази знижувалася за дії цього похідного. Такі зміни активності ферментів можуть спричинити збільшення рівня пероксиду Гідрогену в клітині, який у великих кількостях є токсичним для ракової клітини.

Висновки. Ці результати вказують на те, що досліджуване похідне піразолопіримідину може реалізовувати свою цитотоксичну дію на клітини лімфоми через влив на вміст продуктів пероксидного окиснення ліпідів і активність фрерментів антиоксидантної системи. Отримані дані можуть бути використані для розуміння механізму дії цієї сполуки та подальшого покращення його протипухлинної дії.

Ключові слова: лімфома, похідне піразолопіримідину, пероксидне окиснення ліпідів, антиоксидантна система, протипухлинні препарати 